\title{
Advertising Management Strategies of Chinese Urban Newspaper in the New Media Era
}

\author{
Meigui Ma \\ College of Humanities, Honghe University, Mengzi, Yunnan Province, P.R. China
}

\begin{abstract}
In the new media environment, intensifying competition between media and urban newspaper facing emerging media's impact, their advertising has become a urban newspaper for the survival of business and development. The core of Urban Newspaper advertising business through innovation, optimize advertising structures, integration of internal and external resources and enhance core competitiveness.
\end{abstract}

KEYWORD: New Media; Urban Newspaper; Advertising; Management strategy

With the acceleration of national media group, media's full range of competition, urban newspaper after a dozen years of rapid development in recent years has been slowed down. Advertising is the survival and development of mass media "blood", which is economic growth the most important variable in the media, in the new media environment[1]. Media advertising competition is becoming increasingly fierce. For urban newspaper hit many times from the new media, how to cope with fierce competition in the advertising market, how to reform, development and innovation in the competition is imminent.

\section{CLASSIFIED ADVERTISING BUSINESS, OPTIMIZE STRUCTURE OF ADVERTISING}

Classified ads, also known as the "want ads". Such ads in the form of notice to customers' needs in different plant categories, into different columns, concentrated production in the same title. Urban newspaper classified ads is the city newspaper advertising classified ads on different standards in different sections, concentrated production in the same title. This plant will form short, making simple and rapid spread, low prices, more suitable for individuals or small businesses, small groups are used. Relative to the industrial and commercial advertising, told newspaper classified plant closer to the reader every aspect of life, rich in content and diverse and is suitable for readers ' individual requirements. Classifieds main features are low price, acceptable to workers in general. Moreover, new era, city newspaper advertising classified management strategies can be adopted, classified ads, according to the different needs of business, optimize the structure of ad play urban newspaper is convenient, informative and other advantages, which stand out in the media.

\subsection{Classification of content, layout, and innovation}

Judging from the surveys some of the urban newspaper, classified advertisement business contents and layout are also less than satisfactory situation. Urban newspaper of them confined to narrow range of inspiration, loss, enterprise supply and demand, far from classified ads to play role as a platform for information exchange link. While most cities report has taken into account the category divisions are mostly text features and layout art, sexual attention, but in the actual publication, involving technology and the quality of personnel and other factors, affect classified advertising column appearance clean and tidy. Bring convenience to readers without a discount, affecting the reading and finding of information to a certain extent. Only timely, appropriate and suitable, adequate, appropriate, suitable price, you need suitable information can enter the recipient's brain. Which is reflected in the urban newspaper on the classified ads, is to expand and beautify the layout of its contents and classification of scientific harmony between these three elements, it is also consistent with "simple is beautiful" principle.

\subsection{Implementation of differentiated classified ads}

Differentiation of Urban newspaper classified ad includes content differences and regional differences in two aspects. Content differentiation of the so- 
called classified ads, Urban newspaper business classified ad content should have its own business focus formation strengths in one area, thereby promoting development of the entire classified ads. Such as classified ads accounted for its advertising pages $12 \%$ of Sanqin Urban Newspaper, published in Office equipment factory sued by unique, 21 per cent of its classified ads. 8\%, published the ad's most populous urban newspaper. While the WCC puts "looking for a job, look at newspaper classified ad rubric ads Newspaper classified ads can be focused and comprehensive development strategy, on the one hand in the homogenization of markets to strengthen their differences in order to communicate this to advertisers this advertising advantage of business information, and actively seizing market opportunities; It can also meet the needs of readers at all levels, developing readers ' reading habits.

\subsection{Develop the network classified ads}

Classified ads and newspaper media network platform of joint are $1+1>2$ together to create a high value return. One is the interaction between network media and traditional print media mutual media mix can reduce advertising costs. Second is the classified advertisements for newspaper websites to create a more colorful community space, exploring more rich advertising resources. Third is the network platform technology enables online classified ads to break the bottleneck of dissemination of print ads, truly meet suitable inch, suitable, appropriate, adequate, appropriate, suitable price, you need suitable information requirements, and advertising audience, publishers, advertising agencies, interactive integrated and effective dissemination of information. Databases can be classified as plants will provide comprehensive, real-time, accurate, economical, scientific analysis of advertising data, enhanced location advantages, develop long-term relationships with the user, integration between the user and the newspaper all the relevant info, so that users are far more comprehensive personalized service than traditional media and culture reinforce user loyalty[2].

\section{INTEGRATED MARKETING COMMUNICATIONS, ENHANCE THE CORE COMPETITIVENESS}

In an era of resource sharing, Urban newspaper daily advertisements from various emerging media's impact, but can also be integrated in major media, in the media and media from one another, and take the road to integrated marketing. Under the new media environment, from the urban newspaper of integrated marketing advertising integration of internal and external resources to enhance the core competence of media.

\subsection{Enlarge the vertical integration of internal resources}

A newspaper's market positioning and image integration capabilities, suitable for type of plant will affect it and advertisers industry, also affect its advertising revenue growth, and an untapped potential[3].

In the era of personalized consumer, advertiser's choice of media is also a personalized needs, according to the characteristics of different plants will form. Urban retribution according to the different needs of advertisers, operating two different types of advertising: classified ads and display ads. Classified ads full merger of similar advertising messages, block appeared relatively cheap, generally to the media agency to do, now more common such as medicine, cosmetology, automotive, etc. Display advertising is the most common type of advertising, such as banner and fullpage and half, is more expensive, but the results were quite good.

In advertising layout of creative Shang, some city reported of non-General using very striking, it of advertising layout including: Poker, and article version, and 1 type, and anti-l type, and world version, and across page single pass intaglio, and version core type, and free identifies type, and Lenovo type, and free version core type, and round, and oval, and triangle, and intaglio, and folding etc, great to meet has advertising main of wishes.

In addition to the idea of advertisements, on the introduction of targeted relatively strong, advertisers can also meet the special wishes. If it is done for real estate projects ad-targeting settings, some national newspapers, also placed in their own local version of local advertising, lower prices, targeted, it is quite appealing.

Currently, advertising packages can also open advertisers' appetites. Some newspapers, during the holiday season will be combining their different position and time of advertisement and recommend it to advertising agencies, and given away at a discount.

\subsection{Strengthen the horizontal integration of media resources}

In the background of the integration of old and new media, newspaper revenue model is bound to change. Take full advantage of the complementary principles of media to maximize the advertising effect.

First, the integration of media resources of its kind. Competition between newspapers make possible the joint, shared resources, and achieve a 
total risk, such cooperation from the swap advertising space, cooperation activities, until the share of advertising resources, has been a certain degree of development in the country.

Secondly, cross-media integration. Using the media mix in media buying, combined across media, content sharing, radiant crowds, waiting on the combination of the media, to maximize the advertising effect. More common now are a content level of integration, such as the Beijing science and technology news and $\mathrm{Yi} \mathrm{Lu}$, Beijing advertising company to build the country's first "light box newspaper ".

\section{INNOVATIVE MANAGEMENT MECHANISM, STRENGTHEN TEAM VITALITY}

Innovation is the vitality source of media, but by the soul. Urban newspaper advertising innovations not only in terms of content, layout, and is also reflected in the operating mode and the employing institution [4]. Hangzhou newspaper group after the reform, the pop Media Ltd, Zhejiang was changed from one of the operating divisions of the group, into a complete realization of industrialization, the currency field of operation of the enterprise. They in addition to accomplish advertising business objectives of the group, has developed a market-oriented life DM magazine, fine living website, exhibition, galleries, and investment and financing and other business projects, won a number of Hangzhou portal site, the
Planning Agency for brand and franchise. Newspaper group in Zhejiang province by reforming the traditional means of distribution, advertising management system of the full implementation of Commission, fully reflects the more pay "principle, which ensures the employee's legitimate income, and ensures the completion of newspaper business indicators.

In short, in the new media environment, Urban newspaper facing the strong impact of emerging media, urban newspaper, only continue to tap their own unique resources, timely innovation in order to survive and develop. Urban newspaper of living plant divisions must be based on market trends, consumer needs and conceptual change through classified ads to optimize your advertising and integrated marketing strategy structure, integrate resources and boost competitiveness, to blaze a new road of development of the urban newspaper.

\section{REFERENCES}

[1] Schultz. Integrated marketing communications. China Press. 2001.

[2] Xiaojin GU. Entered the United States newspaper. The NanFang daily press. 10 (2002).

[3] Junjie DING. Guoqing DU, China's advertising industry development present situation and trend thinking. International Ads .09 (2004).

[4] [Hebei daily newspaper group. Newspaper industry advertisement management strategy in the new media ecology. China's newspaper industry. 02 (2007). 